\title{
SOME FEATURES OF A TYPICAL HOUSE AS PERCEIVED BY NATIVE SPEAKERS OF ENGLISH AND OF SERBIAN ${ }^{2}$
}

ABSTRACT. The paper reports findings from one of the two differently-designed surveys conducted among groups of both native speakers of English and native speakers of Serbian with a common general objective to obtain a picture of better candidates for a role of the whole (to be analyzed into its constituent elements) in the contrastive study on the lexical field a house and its parts in English and Serbian. The specific objective of the survey presented here, however, was to build up the target picture with some of the features of the ideal example of the HOUSE category, such as the shape of the house, the key materials its principal structural elements (foundations, walls, a roof) are made of, the number of residential units in the house and the type of the household that occupies it, the number of the house levels, the minimum of its interior spatial components and their functions, the types of systemic parts in the house, the status and position of the house relative to surrounding buildings, etc. Also, taking into consideration that the demographic profiles of the survey participants reflected various cultural backgrounds (which significantly influence the formation of mental images of a typical sample of the category), the survey aimed to compare the similarities and

danya.sm@mts.rs

2 The paper presents the results of research conducted under the Project No. 178019 Translation in the System of Comparative Research of National and Foreign Literature and Culture, which is funded by the Ministry of Education, Science and Technological Development of the Republic of Serbia.

This paper was submitted on 21 August 2015 and accepted for publication at the meeting of the Editorial Board held on 8 October 2015. 
differences between the "English" and the "Serbian" typical house, that is the features assigned to a typical house by most of the surveyed representatives of Anglo-American and by those of Serbian culture.

Judging exclusively by the features observed and the results obtained, the study concludes that the "English" and the "Serbian" typical house look very similar in many aspect and that the two different cultures are not as distant as they may seem.

KEY WORDS: parts and wholes, category HOUSE, prototype, features, English, Serbian.

INTRODUCTION

One of the tasks the author of the paper was faced with in the preparatory stage of selecting the lexical material for the contrastive study on the lexical field $a$ house and its parts in English and Serbian was concerned with the identification and selection of better candidates for a role of the whole (to be analyzed into its constituent elements) from a wide range of quite different kinds of buildings constructed over time and space for people to live in and all placed under the "denotational" roof of both house and kuća (that is the global holonyms of the field in the two languages). ${ }^{3}$ As the initial steps taken in the process - first, imposing a combination of time and space restrictions on the range of the buildings (and their specific characteristics) ${ }^{4}$ and then focusing on only those that nowadays exist or, even narrower, that are nowadays built in the main English and Serbian speaking countries (England, USA, and Serbia) - resulted in still rich diversity of potential candidates for the role ${ }^{5}$ among which the choice of better ones would only

3 A number of other dilemmas and the tasks performed concerning the selection and classification of meronyms of house / kuća are presented in Dilparić, 2014a; 2014b.

4 Profound differences that exist among houses in the context of time and space - with respect to the construction type, architectural style, shape, size of vertical and horizontal extent, materials used, number of residential units, complexity and organization of both interior and exterior design, decorative elements, etc. - are the result of various macro- and micro-factors such as geographical features of the construction sites (climate conditions, geological profile of the land, terrain configuration, flora and fauna available), historical, political, cultural, and socio-economic circumstances in a region, level of technology and masonry skills, as well as the lifestyle and everyday needs of household members, family structure, its assets and social status (also, often the need to express the status and assets through the design of the house), etc. 
reflect the personal views of the author, this choice thus was decided to be left to a number of selectors, that is the two groups of both native speakers of English and native speakers of Serbian. To be more precise, the English and the Serbian speakers were intended to provide a more objective picture of the whole by performing tasks of the two differently-designed surveys, both based on the theory of prototype. ${ }^{6}$

This paper reports the findings of one of the surveys, whereas the other one could be found in Dilparić $(2011 ; 2012 b ; 2012 c)$.

\section{PROCEDURE OF THE SURVEY AND DISCUSSION ON THE RESULTS}

The survey presented here was conducted among sixty five native speakers of (British and American) English and the same number of native speakers of Serbian having as its primary objective to build up the target picture of the whole with some of the features which, according to a majority of the respondents, characterize a prototype of the HOUSE category. Also, taking into consideration that the demographic profiles of the survey participants (summarized in Appendix 1) reflected various cultural backgrounds (which significantly influence the formation of mental images of a typical sample of the category), the survey aimed to compare and contrast the features of a typical house in most of the surveyed representatives of Anglo-American and those of Serbian culture. Therefore, separate respondent groups, as well as their images of a typical house, will here be given different designations - respectively, English and Serbian - solely based on their native language and should not, therefore, be interpreted in any other way.

The participants in the survey were given a multiple choice questionnaire consisting of twenty three questions. Most questions were focused on particular characteristics of the building structure

5 A part of diversity of houses characteristic for these areas is illustrated in Aslet (2004); Barrow (2013); Beeny (2012); Brunskill (2000); Burness (2003); Clemenson (1982); Emery (2000); Foster (2004); Deroko (1964); Jovanović et al. (2012; 2013a; 2013b); Kojić (1980); Nenadović (2002); Rodić (2003).

6 More on the theory of prototype in Mervis \& Rosch (1981); Rosch (1973a; 1973b; 1975a; 1975b; 1977a; 1977b; 1978); Rosch \& Mervis (1975); Rosch et al. (1976); Taylor (1995); Ungerer \& Schmid (1996). 
itself, concerning some of its segmental (structural and spatial) and systemic parts, ${ }^{7}$ while others were concerned with the area around the house as well as its residents in order to get a broader image of the prototype(s). All these questions, together with the respective responses, are given in Appendix 2. Table (i), on the other hand, shows a comparison of the attributes chosen by most of the surveyed representatives of each group. The table also includes two somewhat alternative features of the prototype(s) - item 4 in the Anglo-American group and item 3 in the Serbian group - that is the features which, although selected by most respondents (in a group), do not compare favourably against each other.

Judging exclusively by the features observed and the results obtained, it can be concluded that most survey participants, regardless of their diverse cultural backgrounds, have a very similar image of a typical house, but not without its distinctions. First of all, most participants (of both groups) picture a house as a detached and not very high building occupied by one (family) household, whereby the feature 'not very high' translates as two levels above ground. A more precise definition of the levels, as well as the vertical spreading of a house downward, however, reveal some minor discrepancies between the survey groups: according to the English group, a typical house consists of a ground and a first floor with or without a basement, whereas a typical Serbian house, besides a ground floor, does have a basement and either a first floor or (just) a loft.

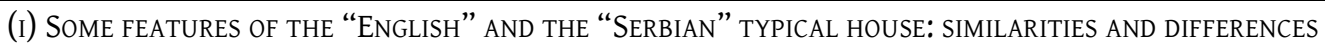

Features of a typical house as perceived by Features of a typical house as perceived most English-speaking respondents by most Serbian-speaking respondents

1. A typical house is occupied by just one household. A typical house is occupied by just one household.

2. People who occupy a typical house are members

$55.4 \%$

People who occupy a typical house are members of a family.

$83.1 \%$ of a family.

3. A typical house has two levels A typical house has two levels above ground, that is a ground above ground, that is (or first) floor and a first (or second) floor.

7 On segmental and systemic parts of wholes in Cruse (1995; 2004); Croft \& Cruse (2004); Dilparić (2012a). 
4. A typical house does not have a basement /

A typical house has a

has a basement.

5. A typical house is a detached type of house.

A typical house is a detached type of house.

A typical house has a

6. A typical house has a rectangular plan. rectangular plan.

7. A typical house rests on

A typical house rests on foundations made of concrete. $80.0 \%$

8. The walls of a typical house are made of clay brick.

foundations made of concrete. $89.2 \%$

The walls of a typical house are made of clay brick.

9. A typical house has a sloped - $100 \%$ gable roof.

10. The roof of a typical house is covered with clay tile.

11. A typical house has a chimney.

12. A typical house has more than one room $100 \%$ at least a kitchen, a room, a A typical house has a sloped - $100 \%$ gable roof.

The roof of a typical house is covered with clay tile.

$90.8 \%$

A typical house has a chimney.

A typical house has more than one room $100 \%$ at least a kitchen, a room, a hallway and a bathroom.

13. A typical house has a yard -

$95.4 \%$ with a fence.

14. A typical house has outbuildings at least a garage.

15. A typical house has electricity.

16. A typical house has water supply.

17. A typical house has a sewage system.

18. A typical house has central heating.

19. A typical house is heated on gas.

$60.0 \%$

20. A typical house has a telephone line hallway and a bathroom.

A typical house has a yard with a fence.

$100 \%$

A typical house has

outbuildings -

at least a garage.

A typical house has electricity.

$100 \%$

A typical house has water supply.

$100 \%$

A typical house has a sewage system.

A typical house does not have central heating.

A typical house is heated on solid fuels.

A typical house has a and Internet access.

but no Internet access.

$56.9 \%$ 
21. A typical house does not have an intercom system.

$83.1 \%$

22. A typical house does not have video surveillance.

23. A typical house does not have an alarm system.
A typical house does not have an intercom system.

$93.9 \%$

A typical house does not have video surveillance.

$96.9 \%$

A typical house does not have $63.1 \%$ an alarm system.
$98.5 \%$

Both groups of respondents attribute the same shape to a typical house and the same (always hard) building materials used in its principal structural elements: a typical house is a rectangular building whose foundations are made of concrete and walls made of clay brick, while its sloped (according to all the respondents) gable roof is covered with clay tile. As also observed by most participants in both groups, a chimney is still present as a roof addition in a typical house despite the fact that some new houses do not have one. This element, however, seems to be a more substantial feature of the Serbian typical house than English: unlike a hundred percent of the Serbian respondents who still see a chimney as an integral part of a typical house, as much as thirty percent of the English respondents exclude this element from the image of a typical house. This result is consistent with yet another finding of the survey: a typical Serbian household uses solid fuels for heating (78.5\% of respondents), whereas a typical English house is heated on gas $(60 \%)$ or electricity (32\%), fuels that do not (necessarily) require the use of a chimney.

Another point of agreement between the two groups of participants is the complexity of the interior of a typical house (which in itself is implied by describing the house as a multi-storey building): none of the respondents from any of the groups sees a typical house as a single-spaced structure. The interior of a typical house is, in fact, a multi-split area / space with even its core divided into several separate functional units: a kitchen, a room, a hallway, and also a bathroom as "the room in the house that has the shortest history" (Worsley 2011). How many other spatial and what other functional units are integral to a typical house were not covered by the scope of this study; yet, the survey has also found that the spatial / functional organization of everyday life of the residents still encompasses an area outside the building frame - a (fenced) yard which a typical house does have and certain types of outbuildings, most often of which is a garage (in both cases). However, as opposed to the yard which is established as a consistent component of both 
English (95.4\%) and Serbian (100\%) prototype, the feature of 'having outbuildings' is shown to be more typical for the Serbian than the English house: as many as almost forty percent of the English respondents, compared to just three percent of the Serbian ones, think of a typical house as the only, not the main, building on the property.

In addition to their structural and spatial features, the two typical residential buildings remain to be closely defined in terms of their systemic parts (if any), and as the survey shows, even in this perspective, the similarities are far greater than the differences. First of all, both prototypes have several house systems which overlap and interpenetrate throughout their structures. Among them, the same four types - electricity, water supply, sewage, and telephone lines - appear to be not only common but also strongly-marked features of both houses judging by the high rate of their selection by (all or almost all) the participants in both groups. On the other hand, central heating and the Internet are the two systems that draw a marked distinction between the observed prototypes: unlike the Serbian house which still lacks both the elements, in the English house they align with the already mentioned prominent systemic parts (central heating $89.2 \%$; Internet $87.7 \%$ ). Finally, one more similarity between the houses emerges: neither of them is characterized by an intercom, a video-surveillance or an alarm system; furthermore, the absence of these systems in both the houses is shown to be their quite steady feature $(83.1 \%-98.5 \%)$, with the alarm system in the English house as the only exception (63.1\%).

CONCLUSION The survey presented here has derived and compared some of the features of a typical house according to most of the surveyed representatives of Anglo-American and of Serbian culture, such as the shape of the house, the key materials its principal structural elements (foundations, walls, a roof) are made of, the number of residential units in the house, the type of the household that occupies it, the number of house levels, the minimum of its interior spatial components and their functions, the types of systemic parts in the house, the status and position of the house relative to surrounding buildings, etc.

The results of the survey show that, despite their diverse cultural backgrounds, the two respondent groups have provided very similar pictures of the HOUSE prototype, both presenting a detached 
rectangular building with concrete foundations, clay-brick walls and a gable clay-tiled roof (still) pierced by a chimney; a singlefamily house consisted of a number of separate interior units (at least a kitchen, a room, a hallway, and a bathroom) which are organized on two levels above ground; a house that has electricity, water supply, sewage, and a telephone line; a house which does not have an intercom, a video-surveillance and an alarm system; a house that is not (yet) the only building in the fenced yard, but is associated with (at least) a garage. The only differences between the two pictures are a central heating system and the Internet that can only be seen on the English one, and a basement and the "whole" first floor which are more precisely drawn on either the Serbian (the former element) or the English picture (the latter one).

Besides these attributes, both pictures also present a range of other elements of the house which, although not covered by the questionnaire, could be derived from the existing ones. For example, the feature of 'having a pitched roof' suggests that the region where the house is situated (at least periodically) experiences heavy precipitation, which then implies the existence of a rainwater system (gutters and downpipes) and roof overhangs (eaves) as vital elements for keeping weather damage to the roof and the exterior walls at a minimum; the feature of 'having a doublepitched roof entails the existence of two roof slopes or pitches which meet at the central, top ridge, forming triangular gables on two sides of the house; the feature of 'covered with a hard roofing material such as clay tile' reflects also existing strong (and often very complex) roof supporting structure, together with its individual parts; the 'multi-storey' feature suggests the presence of not only floors, but also ceilings, stairways and their parts, etc.

Both the explicit and implicit features of the HOUSE prototype(s) represent, at the same time, a foundation stone of a design of "the whole for analysis" in the contrastive study mentioned before. However, having in mind that many details of the design are still obscured, before the process of decomposition, it is necessary to further sharpen the image of the whole - which will (partly) be achieved by the second questionnaire also aimed at a heterogeneous group of participants. 
SOMe Features of A TyPicAl House...

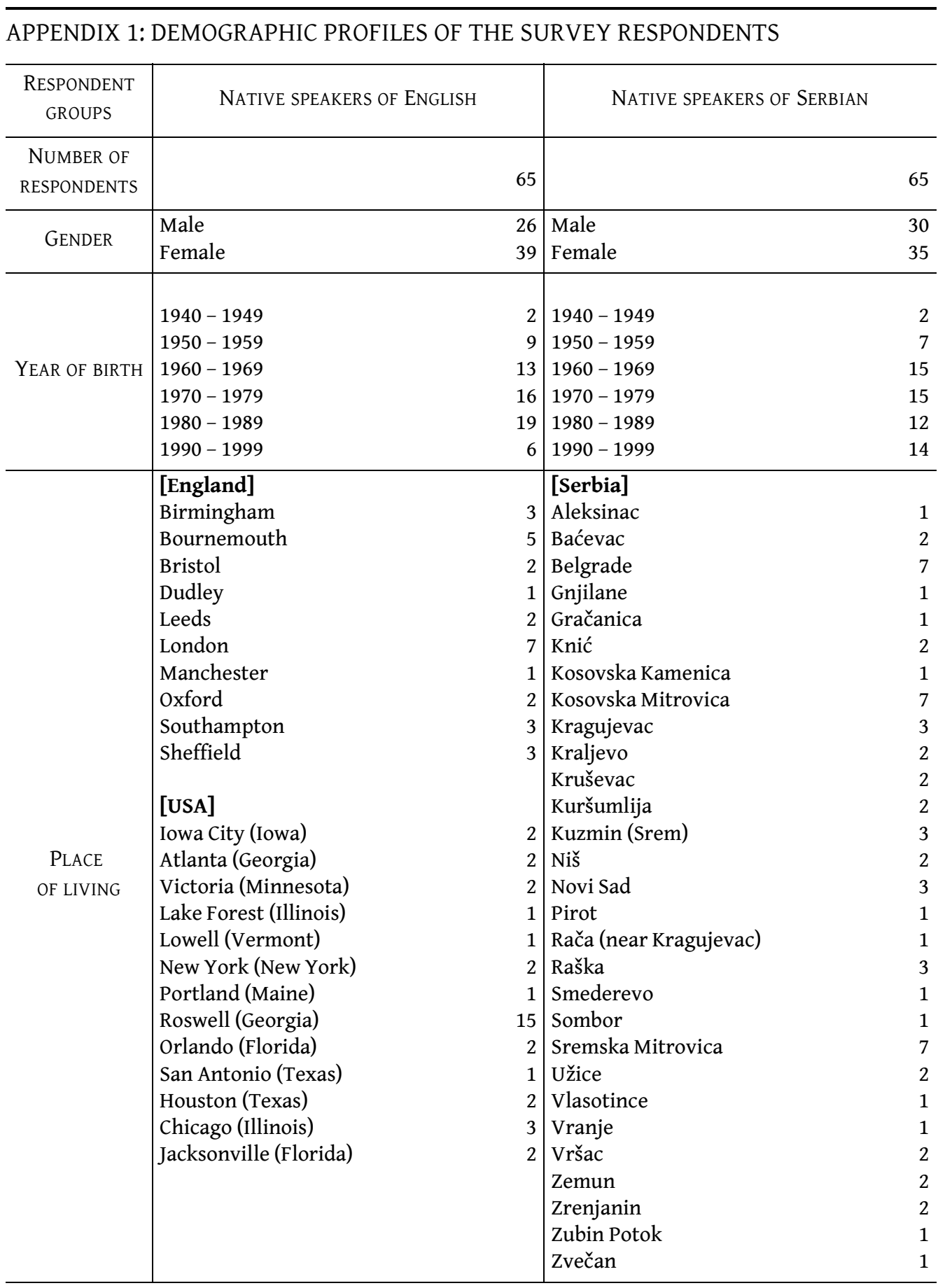


APPENDIX 2: THE SURVEY QUESTIONS AND THE RESPECTIVE RESPONSES

FEATURES OF A TYPICAL HOUSE

\begin{tabular}{lr|lr}
\hline \multicolumn{1}{c|}{ ENGLISH } & \multicolumn{1}{c}{ SERBIAN } \\
$\begin{array}{l}\text { 1. A typical house is occupied by } \\
\text { household(s). }\end{array}$ & & 1. U tipičnoj kući živi - \\
domaćinstvo/-a. & (a) jedno & 41 \\
(a) one & 36 & (b) dva & 14 \\
(b) two & 8 & (c) tri & 3 \\
(c) three & 12 & (d) četiri & 4 \\
(d) four & 4 & (e) više od četiri & 3 \\
(f) more than four & &
\end{tabular}

2. A typical house is occupied by (a) household(s).
(a) family
(b) non-family
(c) single-person
(d) combination of some/all of the above

2. U tipičnoj kući živi _ domaćinstvo / više njih.

3. A typical house has __ storey(s) in height above ground.
(a) one
(b) one and a half
(c) two
(d) two and a half
(e) three
(f) three and a half
(g) four
(h) more than four

4. A typical house a basement.
(a) has
(b) does not have

(a) porodično

(b) neporodično

(c) jedna osoba (po domaćinstvu)

(d) kombinovano

3. Tipična kuća ima _.

(a) samo prizemlje $\quad 10$

4 (b) prizemlje i potkrovlje 20

42 (c) prizemlje i sprat 22

3 (d) prizemlje, sprat i potkrovlje 9

3 (e) prizemlje i dva sprata 4

0 (f) prizemlje, dva sprata i potkrovlje 0

3 (g) prizemlje i tri sprata 0

0 (h) prizemlje i više od tri sprata 0

4. Tipična kuća _ podrum.

$\begin{array}{lll}32 & \text { (a) ima } & 40 \\ 33 & \text { (b) nema } & 25\end{array}$

5. A typical house _ joined to another (neighbo(u)ring) house ( $\_$).
(a) is not
(b) is ... (on one side)
(c) is ... (on both sides)

5. Tipična kuća _ zajednički zid sa drugom (susednom) kućom ( _ ).

6. A typical house has a __ plan.
(a) circular
(b) rectangular
(c) square

6. Osnova tipične kuće je _..

0 (a) kružnog oblika 0

46 (b) pravougaonog oblika 40

10 (c) kvadratnog oblika 19 

(d) L-shaped
(e) U-shaped
(f) T-shaped
(g) none of the above

7. A typical house foundations are made of
(a) wood
(b) stone
(c) concrete
(d) none of the above

8. The walls of a typical house are made of .
(a) wood
(b) stone
(c) adobe brick
(d) clay brick
(e) clay block
(f) concrete block
(g) poured concrete
(h) glass
(i) none of the above

9. A typical house has a _ roof.
(a) flat
(b) shed / lean-to
(c) gable
(d) hip
(e) pyramid-like
(f) cross-gabled
(g) cross-hipped
(h) gambrel
(i) mansard
(j) dome
(k) none of the above [see the picture below]

5 (d) $\Gamma$-oblika 3

0 (e) П-oblika 0

4 (f) T-oblika 1

0 (g) nijedno od navedenog 2

7. Temelji tipične kuće napravljeni su od

5 (a) drveta 0

(b) kamena 7

52 (c) betona 58

2 (d) nijedno od navedenog 0

8. Zidovi tipične kuće napravljeni su od

18 (a) drveta 0

8 (b) kamena 0

0 (c) ćerpiča 0

37 (d) cigle 38

1 (e) blokova 21

1 (f) betonskih blokova 6

0 (g) nalivenog betona 0

0 (h) stakla 0

0 (i) nijedno od navedenog 0

9. Krov tipične kuće je
(a) ravan

(b) kos - sa jednom kosinom

(c) kos - sa dve kosine $\quad 41$

(d) kos - sa četiri kosine (oblika piramide)

(e) kos - sa četiri kosine (oblika piramide ,zasečenog” vrha) 7

(f) kos - izlomljen (osnove Г-, П-, Toblika i otud sa više kosina) 4

(g) mansardni 0

(h) kupolast, svodast 0

(i) nijedno od navedenog 0 


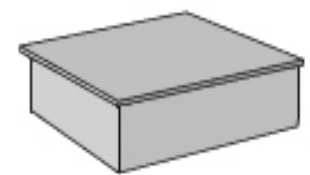

flat

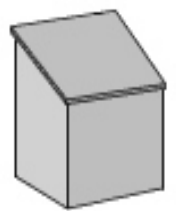

lean-to

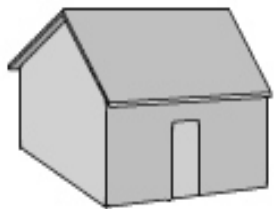

gable

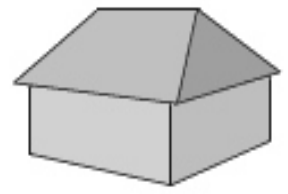

hip

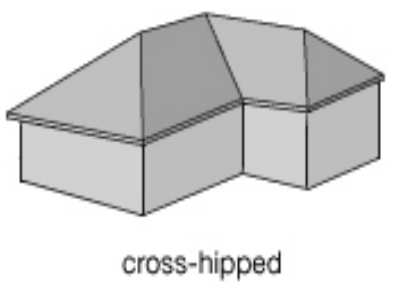

(C) 2007 Encyclopadia Britannica, Inc

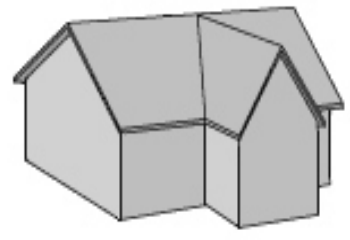

cross-gabled
10. A typical house is covered with
(a) straw
(b) reed
(c) clay tile
(d) concrete tile
(e) wood shingle
(f) metal shingle
(g) asphalt shingle
(h) (stone) slate
(i) none of the above

11. A typical house a chimney.
(a) has
(b) does not have

10. Tipična kuće prekrivena je
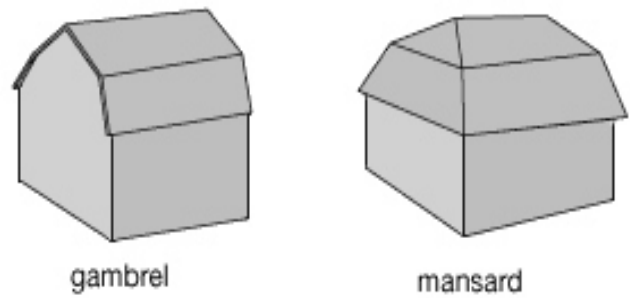

mansard
(a) slamom
(b) trskom
(c) crepom
(d) betonskim pločama
(e) šindrom (drvenim daščicama) 0
(f) metalnim pločama 0
8 (g) tegolom (asfaltnim crepom) 6
7 (h) kamenim pločama 0
3 (i) nijedno od navedenog 0

11. Tipična kuća _ dimnjak.
(a) ima
65
(b) nema
0

19 
12. A typical house _ more than one room ( _ ).

(a) does not have

(b) has ... (at least: a kitchen and a room)

(c) has ... (at least: a room and a bathroom)

(d) has ... (at least: a room and a hallway)

(e) has ... (at least: a kitchen, a room and a bathroom)

(f) has ... (at least: a kitchen, a room and a hallway)

(g) has ... (at least: a kitchen, a room, a hallway and a bathroom)

(h) has ... (at least: none of the above)

13. A typical house a yard (_).
(a) does not have
(b) has ... (with a fence)
(c) has ... (without a fence)

14. A typical house _ outbuildings ( _ ).
(a) does not have
(b) has ... (at least: a shed)
(c) has ... (at least: a garage)
(d) has ... (at least: an outbuilding for keeping animals)
(e) has ... (at least: none of the above)

15. A typical house electricity.
(a) has
(b) does not have

16. A typical house _ water supply.
(a) has
(b) does not have

17. A typical house a sewage system.
(a) has
(b) does not have

18. A typical house central heating.
(a) has
(b) does not have

12. Tipična kuća _ više od jedne prostorije (_).

(a) nema 0

(b) ima ... (najmanje sobu i kuhinju) 3

(c) ima ... (najmanje sobu i kupatilo) 4

(d) ima ... (najmanje sobu i

predsoblje)

0

(e) ima ... (najmanje sobu, kuhinju i

kupatilo)

(f) ima ... (najmanje sobu, kuhinju i predsoblje)

(g) ima ... (najmanje sobu, kuhinju, kupatilo i predsoblje)

(h) ima ... (najmanje: nijedno od navedenog)

13. Tipična kuća _ dvorište ( _ ).

(a) nema 0

(b) ima ... (ograđeno) 62

(c) ima ... (neograđeno)

14. Tipična kuća _ pomoćne objekte ( $)$

(a) nema

(b) ima ... (najmanje šupu)

(c) ima... (najmanje garažu)

(d) ima... (najmanje neki od objekata

2 za čuvanje životinja)

(e) ima... (najmanje: nijedno od navedenog)

15. Tipična kuća _ struju.
(a) ima
65

(b) nema

16. Tipična kuća _ vodu.

65
(a) ima
65

(b) nema

17. Tipična kuća _ kanalizaciju.
(a) ima

(b) nema

18. Tipična kuća _ centralno grejanje.
(a) ima
(b) nema 
19. A typical house is heated on
(a) solid fuels
(b) oil
(c) gas
(d) electricity
(e) solar energy

20. A typical house__a telephone line (_)
(a) does not have
(b) has ... (and Internet, too)
(c) has ... (but does not have Internet)

21. A typical house an intercom system.

(a) has

(b) does not have video-surveillance.

22. A typical house
(a) has
(b) does not have

23. A typical house _ an alarm system.
(a) has
(b) does not have

19. Tipična kuća se zagreva _..
(a) čvrstim gorivom
51
0
(c) gasom
6
(d) strujom
8
(e) solarnom energijom
0

4 (b) naftom

39

21

0

20. Tipična kuća _ telefon (_ ) .

1 (a) nema 1

57 (b) ima ... (i, takođe, internet) 27

7 (c) ima ... (ali ne i internet) 37

21. Tipična kuća _ interfon.

11 (a) ima $\quad 4$

54 (b) nema 61

22. Tipična kuća _ video nadzor.

\begin{tabular}{r|r}
6 & (a) ima \\
59 & (b) nema
\end{tabular}

23. Tipična kuća _ alarm.

$\begin{array}{lr}\text { (a) ima } & 1 \\ \text { (b) nema } & 64\end{array}$


REFERENCES Aslet, C. (2004). The American Country House. Yale University Press.

Barrow, M. (2013). Houses in England. Project Britain: British Life and Culture. Available at http://projectbritain.com/houses/main/index.html [Oct. 2012].

Beeny, S. (2012). A History of British Homes. BBC. 16 February 2012. Available at http://www.bbc.co.uk/news/entertainment-arts-17048794 [Nov. 2012].

Brunskill, R. W. (2000). Houses \& Cottages of Britain: Origins and Development of Traditional Buildings. London: The Orion Publishing Group.

Burness, T. (2003). The Vintage House Book: Classic American Homes 1880-1980. Iola, WI: Krause Publications.

Clemenson, H. A. (1982). English Country Houses and Landed Estates. London: Croom Helm.

Croft, W. \& Cruse, D. A. (2004). Cognitive Linguistics. Cambridge: Cambridge University Press.

Cruse, D. A. (1995). Lexical Semantics. Second Edition. Cambridge: Cambridge University Press.

Cruse, D. A. (2004). Meaning in Language. An Introduction to Semantics and Pragmatics. Oxford: Oxford University Press.

Deroko, A. (1964). Folklorna arhitektura u Jugoslaviji. Beograd: Naučna knjiga.

Dilparić, B. (2011). Unutrašnja struktura kategorije DELOVI KUĆE. Filolog: časopis za jezik, književnost $i$ kulturu 4. Banja Luka: Univerzitet u Banjoj Luci, Filološki fakultet, 132-146.

Dilparić, B. (2012a). O meronimiji. Zbornik radova Filozofskog fakulteta XLII/1. Kosovska Mitrovica: Filozofski fakultet Univerziteta u Prištini, 279-307.

Dilparić, B. (2012b). Semantic Organization of the HOUSE PARTS Category as Perceived by American Subjects. Prevod u sistemu komparativnih izučavanja nacionalne i strane književnosti $i$ kulture (Međunarodni tematski zbornik radova). Kosovska Mitrovica: Filozofski fakultet Univerziteta u Prištini, 285-298.

Dilparić, B. (2012c). Semantička organizacija delova kuće prema srpskim i američkim ispitanicima. Philologia: Naučno-stručni časopis za jezik, književnost $i$ kulturu 10. Beograd: Philologia, 49-59.

Dilparić, B. (2014a). Kriterijumi za određivanje meronimije denotata 'kuća' u fazi odabira i organizacije istraživačke građe: problemi i dileme. Zbornik radova Filozofskog fakulteta XLIV/2. Kosovska Mitrovica: Filozofski fakultet Univerziteta u Prištini, 335-369.

Dilparić, B. (2014b). O (mogućem) opsegu kategorije HOUSE. Zbornik radova Filozofskog fakulteta XLIV/3. Kosovska Mitrovica: Filozofski fakultet Univerziteta u Prištini, 115-172. 
Emery, A. (2000). Greater Medieval Houses of England and Wales. Volume II: East Anglia, Central England and Wales. Cambridge: Cambridge University Press.

Foster, G. L. (2004). American Houses: A Field Guide to the Architecture of the Home. New York: Houghton Mufflin Company.

Jovanović Popović, M., Ignjatović, D., Radivojević, A., Rajčić, A., Đukanović, Lj., Ćuković Ignjatović, N. \& Nedić, M. (2012). Atlas of Family Housing in Serbia. Belgrade: Faculty of Architecture, University of Belgrade; GIZ - Deutche Gesellschaft für Internationale Zusammenarbeit.

Jovanović Popović, M., Ignjatović, D., Radivojević, A., Rajčić, A., Đukanović, Lj., Ćuković Ignjatović, N. \& Nedić, M. (2013a). Atlas of Multifamily Housing in Serbia. Belgrade: Faculty of Architecture, University of Belgrade; GIZ Deutche Gesellschaft für Internationale Zusammenarbeit.

Jovanović Popović, M., Ignjatović, D., Radivojević, A., Rajčić, A., Đukanović, Lj., Ćuković Ignjatović, N. \& Nedić, M. (2013b). National Typology of Residential Buildings in Serbia. Belgrade: Faculty of Architecture, University of Belgrade; GIZ - Deutche Gesellschaft für Internationale Zusammenarbeit.

Kojić, arh. B. (1980). Razvoj kuće i kulture stanovanja u selima Srbije. Glasnik Etnografskog muzeja u Beogradu 44, 53-74.

Mervis, C. B. \& Rosch, E. (1981). Categorization of Natural Objects. Annual Review of Psychology 32, 89-115.

Nenadović, S. M. (2002). Ilustrovani rečnik izraza u narodnoj arhitekturi. Beograd: Prosveta.

Rodić, Z. (2003). Seoska kuća i stanovanje. Narodna kultura Srba u XIX i XX veku. Vodič kroz stalnu postavku. Beograd: Etnografski muzej u Beogradu, 189-250.

Rosch, E. H. (1973a). Natural Categories. Cognitive Psychology 4/3, 328-350.

Rosch, E. (1973b). On the Internal Structure of Perceptual and Semantic Categories. In T. A. Moore (ed.), Cognitive Development and the Acquisition of Language. New York: Academic Press, 111-144.

Rosch, E. (1975a). Cognitive Reference Points. Cognitive Psychology 7/4, 532-547.

Rosch, E. (1975b). Cognitive Representations of Semantic Categories. Journal of Experimental Psychology: General 104/3, 192-233.

Rosch, E. (1977a). Classification of Real-World Objects: Origins and Representations in Cognition. In P. N. Johnson-Laird \& P. C. Wason (eds.), Thinking: Readings in Cognitive Science. Cambridge: Cambridge University Press, 212-222.

Rosch, E. (1977b). Human Categorization. In N. Warren (ed.), Advances in Cross-Cultural Psychology 1. London: Academic Press, 1-72. 
Rosch, E. (1978). Principles of Categorization. In E. Rosch \& B. B. Lloyd (eds.), Cognition and Categorization. Hillsdale, N. J.: Lawrence Earlbaum Associates, 27-48.

Rosch, E. \& Mervis, C. B. (1975). Family Resemblances: Studies in the Internal Structure of Categories. Cognitive Psychology 7/4, 573-605.

Rosch, E., Mervis, C. B., Gray, W. D., Johnson, D. M. \& Boyes-Braem, P. (1976). Basic Objects in Natural Categories. Cognitive Psychology 8/3, 382-439.

Taylor, J. R. (1995). Linguistic Categorization: Prototypes in Linguistic Theory. New York: Oxford University Press.

Ungerer, F. \& Schmid, H.-J. (1996). An Introduction to Cognitive Linguistics. London and New York: Longman.

Worsley, Dr L. (2011). History of the Home. BBC. 11 April 2011. Available at http://www.bbc.co.uk/history/british/middle_ages/history_of_home.shtml [Nov. 2012]. 
БРАНИСЛАВА М. ДИЛПАРИЋ

УНИВЕРЗИТЕТ У ПРИШТИНИ С ПРИВРЕМЕНИМ СЕДИШТЕМ

У КОСОВСКОЈ МИТРОВИЦИ, ФИЛОЗОФСКИ ФАКУЛТЕТ

КАТЕДРА ЗА ЕНГЛЕСКИ ЈЕЗИК И КЮИЖЕВНОСТ

РЕЗИМЕ

НЕКЕ КАРАКТЕРИСТИКЕ ТИПИЧНЕ КУЋЕ

ПРЕМА ИЗВОРНИМ ГОВОРНИЦИМА ЕНГЛЕСКОГ И СРПСКОГ ЈЕЗИКА

У раду су представљени резултати једне од две организоване анкете са изворним говорницима енглеског и изворним говорницима српског језика чији је заједнички циљ био да осликају боље кандидате за улогу „целине за разлагање” у контрастивном испитивању лексичког поља кућа и њени gелови из два поменута језика. Примарни циљ овде представљене анкете пак био је да издвоји и датој слици придружи (тек) неке од атрибута које, према мишљењу већине испитаника, одликују најбољег представника категорије куЋА: облике и кључне материјале од којих су главни структурни елементи ове грађевине (темељи, зидови, кров) направљени, минималне чиниоце њеног просторног састава и њихове функције, границе њеног простирања по вертикали, типове њених системских делова, њен статус и позицију у односу на објекте у непосредном окружењу, број и тип(ове) домаћинст(а)ва који у њој живи / живе итд.

Такође, узевши у обзир да су структуру испитаника чиниле особе које потичу из различитих културних окружења (као фактора који знатно утиче на формирање менталне представе типичног узорка (и) посматране категорије), овим истраживањем покушано је да се утврди и које се то сличности и разлике испољавају између „енглеске” и „српске” типичне куће, тј. издвојених карактеристика прототипа куће од стране већине испитиваних припадника англоамеричке, с једне, и српске културе, с друге стране.

Међутим, судећи искључиво према посматраним, те издвојеним карактеристикама у овој анкети, студија закључује да две поменуте културе ипак нису толико удаљене колико се у први мах то може учинити. Јер, добијене слике прототипа куће приказују, у ствари, подоста сличан призор којег чини индивидуална (слободностојећа) кућа са двориштем (и оградом) у којој живи једна породица; кућа правоугаоног облика која има коси, двоводни кров из ког (још увек) израња димњак; кућа саграђена од чврстих материјала (темељи од ठетона, зидови од цигле, кров 
прекривен црепом); кућа са вишеструко издељеним унутрашњим простором организованим на два надземна нивоа у чијем језгру се налазе кухиња, соба, предсобље и купатило; кућа која има струју, воду, канализацију и телефон, а нема интерфон, аларм нити видео надзор; кућа која је (још увек) главна зграда на имању и уз коју још најмање стоји гаража. Разлике које се међу посматраним сликама такође јављају су, с друге стране, малоठројне, а чине их интерфон и систем централног грејања који су приказани само на енглеској слици, те подрум и „читав” (први) спрат који су јасније нацртани на српској слици (први елемент) или пак на енглеској слици (други елемент).

Речена обележја прототипа категорије куЋА, као и низ посредно изведених елемената ове куће, чине уједно и основу нацрта целине која ће се у поменутом контрастивном истраживању разлагати на своје делове. Али, имајући у виду да су многи детаљи овог нацрта и даље поприлично магловити, пре самог процеса разлагања дате целине неопходно је да се њена слика и додатно изоштри - што ће, донекле, учинити још једна група „мешовитих” испитаника, учесника друге поменуте анкете.

Кључне речи: делови и целине, категорија кућа, прототип, карактеристике, енглески, српски. 